\title{
Genetic modifiers of hypertension in soluble guanylate cyclase $\alpha 1$-deficient mice
}

\author{
Emmanuel S. Buys, ${ }^{1}$ Michael J. Raher, ${ }^{1}$ Andrew Kirby, ${ }^{2}$ Shahid Mohd, ${ }^{1}$ David M. Baron, ${ }^{1}$ \\ Sarah R. Hayton, ${ }^{1}$ Laurel T. Tainsh, ${ }^{1}$ Patrick Y. Sips, ${ }^{1}$ Kristen M. Rauwerdink, ${ }^{1}$ Qingshang Yan, ${ }^{3}$ \\ Robert E.T. Tainsh, ${ }^{1}$ Hannah R. Shakartzi, ${ }^{1}$ Christine Stevens, ${ }^{2}$ Kelly Decaluwé, ${ }^{4}$ \\ Maria da Gloria Rodrigues-Machado, ${ }^{1}$ Rajeev Malhotra, ${ }^{5}$ Johan Van de Voorde, ${ }^{4}$ Tong Wang, ${ }^{3}$ \\ Peter Brouckaert, ${ }^{6,7}$ Mark J. Daly, ${ }^{2}$ and Kenneth D. Bloch ${ }^{1,5}$

\begin{abstract}
${ }^{1}$ Anesthesia Center for Critical Care Research, Department of Anesthesia, Critical Care, and Pain Medicine, and ${ }^{2}$ Center for Human Genetic Research, Department of Medicine, Massachusetts General Hospital, Harvard Medical School, Boston, Massachusetts, USA.

${ }^{3}$ Department of Cellular and Molecular Physiology, School of Medicine, Yale University, New Haven, Connecticut, USA. ${ }^{4}$ Department of Pharmacology, Ghent University, Ghent, Belgium. ${ }^{5}$ Cardiology Division, Department of Medicine, Massachusetts General Hospital, Harvard Medical School,
\end{abstract} \\ Boston, Massachusetts, USA. ${ }^{6}$ Department of Biomedical Molecular Biology, Ghent University, Ghent, Belgium.
}

7Department of Molecular Biomedical Research, VIB, Ghent, Belgium.

\begin{abstract}
Nitric oxide (NO) plays an essential role in regulating hypertension and blood flow by inducing relaxation of vascular smooth muscle. Male mice deficient in a NO receptor component, the $\alpha 1$ subunit of soluble guanylate cyclase $\left(\mathrm{sGC \alpha}_{1}\right)$, are prone to hypertension in some, but not all, mouse strains, suggesting that additional genetic factors contribute to the onset of hypertension. Using linkage analyses, we discovered a quantitative trait locus (QTL) on chromosome 1 that was linked to mean arterial pressure (MAP) in the context of sGC $\alpha_{1}$ deficiency. This region is syntenic with previously identified blood pressure-related QTLs in the human and rat genome and contains the genes coding for renin. Hypertension was associated with increased activity of the renin-angiotensin-aldosterone system (RAAS). Further, we found that RAAS inhibition normalized MAP and improved endothelium-dependent vasorelaxation in sGC $\alpha_{1}$-deficient mice. These data identify the RAAS as a blood pressure-modifying mechanism in a setting of impaired NO/cGMP signaling.
\end{abstract}

\section{Introduction}

Systemic arterial hypertension is one of the most widespread public health problems in the developed world and the most prevalent modifiable risk factor for cardiovascular disease (CVD) in both women and men (1). The pathogenesis of essential hypertension is multifactorial, and in the vast majority of cases the etiology of hypertension is unknown. Although major advances in the treatment of hypertension have decreased CVD-related deaths over the last decade (2), many of the molecular mechanisms underlying the development of hypertension remain elusive. Genome-wide association studies (GWAS) suggest that there is a substantial heritable component to blood pressure $(3,4)$. Although GWAS have identified several loci associated with blood pressure in human beings, including loci containing genes that either regulate cGMP levels (4-7) or the renin-angiotensin-aldosterone system (RAAS) (8), many of the genetic factors determining blood pressure and how these factors interact remain to be identified.

Renal abnormalities, such as decreased urinary sodium excretion in response to increasing renal perfusion pressure, and increased activity of the RAAS are generally considered to be a major contributor to the development of high blood pressure (9). However, other studies support the idea that hypertension can arise from primary vascular abnormalities $(10,11)$. The ability of NO to relax vascular smooth muscle and its essential role in the regulation of blood flow are well characterized $(12,13)$. Ample evidence suggests that altered NO signaling is involved in the pathogenesis of hypertension (14).

One of the primary receptors for $\mathrm{NO}$ is soluble guanylate cyclase (sGC), a heme-containing enzyme that generates cGMP. The

Conflict of interest: The authors have declared that no conflict of interest exists. Citation for this article: J Clin Invest. 2012;122(6):2316-2325. doi:10.1172/JCI60119. impact of $\mathrm{NO}$ on the cardiovascular system is mediated, at least in part, by cGMP-dependent mechanisms (15). sGC is a heterodimeric enzyme, consisting of $\alpha$ and $\beta$ subunits. Two isoforms of each subunit have been identified $\left(\alpha_{1}, \alpha_{2}, \beta_{1}, \beta_{2}\right)$, but only sGC $\alpha_{1} \beta_{1}$ and ${ }_{s G C} \alpha_{2} \beta_{1}$ appear to function in vivo (16). Although the $s G C \alpha_{1} \beta_{1}$ heterodimer is the most abundant sGC isoform in the cardiovasculature (17), low levels of cGMP, generated by sGC $\alpha_{2} \beta_{1}$, are sufficient to mediate many of NO's cardiovascular effects $(15,18-20)$.

The role of $\mathrm{sGC}_{1} \beta_{1}$ in regulating blood pressure in humans and the importance of sGC as a potential therapeutic target for hypertension were recently highlighted in a GWAS identifying a locus that influences blood pressure and that contains the genes encoding the sGC $\alpha_{1}$ and $\mathrm{sGC} \beta_{1}$ subunits (7). We previously reported that male but not female mice deficient for $\mathrm{sGC} \alpha_{1}$ on a $129 \mathrm{~S} 6$ (S6) background ( $\mathrm{SGC}_{1}^{-/-\mathrm{S} 6}$ ) develop hypertension (18). These effects appear to be modulated by genetic factors, because male sGCa ${ }_{1}^{-/-}$mice on the C57BL/6 (B6) background $\left(\mathrm{sGCa}_{1}^{-/-\mathrm{B} 6}\right)$ do not develop hypertension. The underlying pathophysiological mechanisms responsible for the differential impact on blood pressure of impaired NO/cGMP signaling in these inbred strains of mice remained unknown. Therefore, we sought to identify genetic determinants critical to the development of hypertension in $\mathrm{sGC} \alpha_{1}^{-/-\mathrm{S} 6}$ mice using an unbiased linkage analysis approach. Moreover, we characterized the role of a candidate gene (renin), identified in the linkage analysis, in the hypertension associated with deficient $\mathrm{NO} / \mathrm{cGMP}$ signaling.

\section{Results}

Identification of a blood pressure quantitative trait locus on chromosome 1, and renin as a candidate modifier gene for blood pressure in $s G C \mathrm{\alpha}_{1}^{-/}$ mice. As previously described $(18,21)$, mean arterial blood pres- 


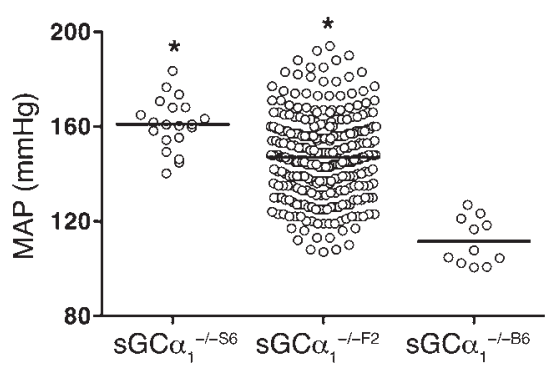

Figure 1

Genetic background affects blood pressure in $\mathrm{sGC} \alpha_{1}^{-/-}$mice. MAP measured invasively in anesthetized male sGC $\alpha_{1}^{-/-F 2}$ mice $(n=284$ mice) lies between MAP observed in male $\mathrm{sGC}_{1}{ }^{-1-\mathrm{B} 6}$ and $\mathrm{sGC} \alpha_{1}^{-1-\mathrm{S} 6}$ mice ( $n=11$ and 20 , respectively). ${ }^{*} P<0.001$ versus all other groups by 1-way ANOVA.

sure (MAP) was higher in male $\mathrm{sGC} \alpha_{1}^{-/-\mathrm{S} 6}$ mice than in $\mathrm{sGC} \alpha_{1}^{-/-\mathrm{B} 6}$ mice (161 \pm 2 and $112 \pm 3 \mathrm{mmHg}$, respectively; Figure 1). This difference in blood pressure between inbred $\mathrm{sGCa}_{1}{ }^{-/-}$strains confirms a strong genetic influence on the regulation of blood pressure in $\mathrm{sGCa}_{1}{ }^{-/-}$mice. To exploit this difference for identification of modifier genes of blood pressure, we performed a reciprocal $\mathrm{F}_{1}$ intercross between $\mathrm{sGC \alpha} \alpha_{1}^{-/-\mathrm{B} 6}$ and $\mathrm{sGC}_{1}{ }^{-/-\mathrm{S} 6}$ mice. $\mathrm{sGC \alpha} \alpha_{1}^{-/-\mathrm{F} 2}$ progeny exhibited a large variance in MAP, ranging from values observed in $\mathrm{sGC} \alpha_{1}{ }^{-/-\mathrm{B} 6}$ to values observed in $\mathrm{sGC}_{1}{ }^{-/ \mathrm{S} 6}$ mice, demonstrating that the hypertension associated with $\mathrm{sGC} \alpha_{1}$ deficiency is preserved in a subset of mice in the $\mathrm{F}_{2}$ cross (Figure 1). Using the phenotypic variance in genetically homogeneous parental and $F_{1}$ mice as an estimate of the trait's variation from environmental influences and the phenotypic variance in $\mathrm{F}_{2}$ mice as an estimate of the trait's variation from both genetic and environmental influences, we estimated the broad heritability of the trait to be greater than 0.5 .

A linkage analysis in a first cohort of $92 \mathrm{~F}_{2}$ mice, using 120 genome-wide SNPs, identified a quantitative trait locus (QTL) on chromosome 1 that influences blood pressure (lod score, 3.0; Supplemental Figure 1; supplemental material available online with this article; doi:10.1172/ JCI60119DS1). Genotyping of a second independent cohort of 96 additional $\mathrm{F}_{2}$ mice yielded a collective lod score of 5.3 at the chromosome 1 locus (genome-wide corrected, $P=0.006$; Supplemental Figures 2 and 3). To refine the linkage peak through additional recombinants and higher marker density, the original 188 mice and a third independent cohort of 96 $\mathrm{F}_{2}$ mice were genotyped for 28 SNPs across the QTL on chromosome 1. Linkage at this locus was highly significant, with a final lod score of 6.3 (genome-wide corrected, $P=0.0006$ ) (Figure 2). We designated this locus Hsgcq (hypertension associated with sGC $\alpha_{1}$-deficiency QTL). Two other loci of interest were identified, on chromosomes 4 and 9, with maximal lod scores of 3.6 and 3.9, respectively. Here, we focused on the locus ( $H s g c q)$ with the highest lod score.

Hsgcq was localized to a position close to Mm37-1-130689858 (Figure 2). The 1.5 lod confidence interval spanned a region on chromosome 1 between Mm37-1-119319789 and Mm37-1158911588. One of the genes in this region is renin 1 (position on chromosome 1: 135,247,143-135,256,900), a candidate modifier gene of hypertension (22). Mice on the B6 background have one renin gene (renin 1c), whereas mice on the $\mathrm{S} 6$ background have two renin genes, designated renin $1 \mathrm{~d}$ and renin 2 (23-25). In addition, when comparing the genomic DNA sequence of renin $1 \mathrm{c}$ and renin $1 \mathrm{~d}(\sim 10,000 \mathrm{bp})$, we identified 201 nucleotide substitutions and 126 nucleotide insertions or deletions, resulting in a sequence variability of $3.3 \%$. We identified 21 nucleotides that were different between renin $1 \mathrm{c}$ and renin $1 \mathrm{~d}$ cDNA (1,592 bp for both; Supplemental Figure 4). On the protein level, we identified 5 amino acid differences (of 402 amino acids): R58W, I68T, V160S, D315E, and Y352N (Supplemental Figure 5).

Renal renin 1 gene expression, assessed using quantitative RTPCR (qRT-PCR), was similar in B6 mice and in S6 mice of either genotype (Figure 3A). No difference was observed in renal renin 2 mRNA levels between $\mathrm{sGC \alpha _{1 } - \text { -S6 }}$ and wild-type mice on the S6 background (WT ${ }^{\mathrm{S} 6}$; Figure 3B). qRT-PCR confirmed the absence of renin 2 expression in both $\mathrm{sGC \alpha}_{1}^{-/-\mathrm{B} 6}$ and $\mathrm{WT}^{\mathrm{B} 6}$ mice (Figure $3 \mathrm{~B}$ ).

To evaluate the impact of the renin genotype on blood pressure, we grouped sGC $\alpha_{1}^{-/-F 2}$ mice according to their renin genotype. Seventy-six mice were homozygous for renin 1c, 73 mice were homozygous for renin $1 \mathrm{~d}$ and renin 2, and 135 mice were heterozygous. Presence of the renin $1 \mathrm{~d}$ and renin 2 genes was associated with increased blood pressure in a dominant manner: while MAP was $139 \pm 2 \mathrm{mmHg}$ in mice homozygous for renin 1c, MAP was $150 \pm 2$ and $152 \pm 2 \mathrm{mmHg}$ in mice that were heterozygous and homozygous, respectively, for renin $1 \mathrm{~d}$ and renin 2 (Figure 4). These findings confirm that renin $1 \mathrm{~d}$, renin 2 , or a closely linked gene functions as a dominant modifier gene for blood pressure in

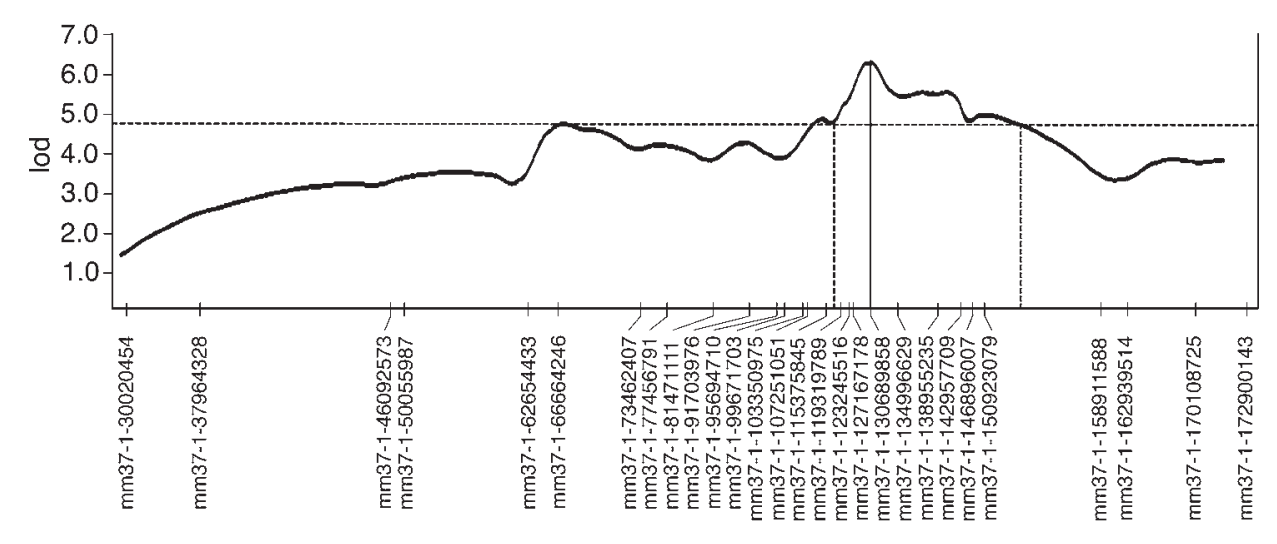

\section{Figure 2}

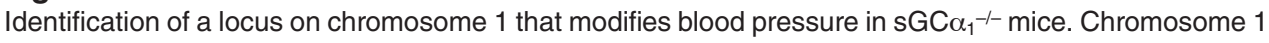
fine mapping for blood pressure, performed using $28 \mathrm{SNPs}$ in 284 male $\mathrm{sGC}_{\alpha_{1}}^{-/-\mathrm{F} 2}\left(\mathrm{sGC}_{1}{ }^{-/-\mathrm{S} 6} \times\right.$ $\left.\mathrm{sGC} \alpha_{1}{ }^{-l-\mathrm{B} 6}\right)$ progeny. The SNP markers are plotted on the $x$ axis, spaced according to cross-derived recombination distances. The $y$ axis represents the lod scores. A highly significant lod score of 6.3 $(P=0.0006)$ was obtained at Mm37-1-130689858 (marked by a vertical line). The $95 \%$ confidence interval $(1.5 \mathrm{lod})$ is flanked by vertical dashed lines. 
A
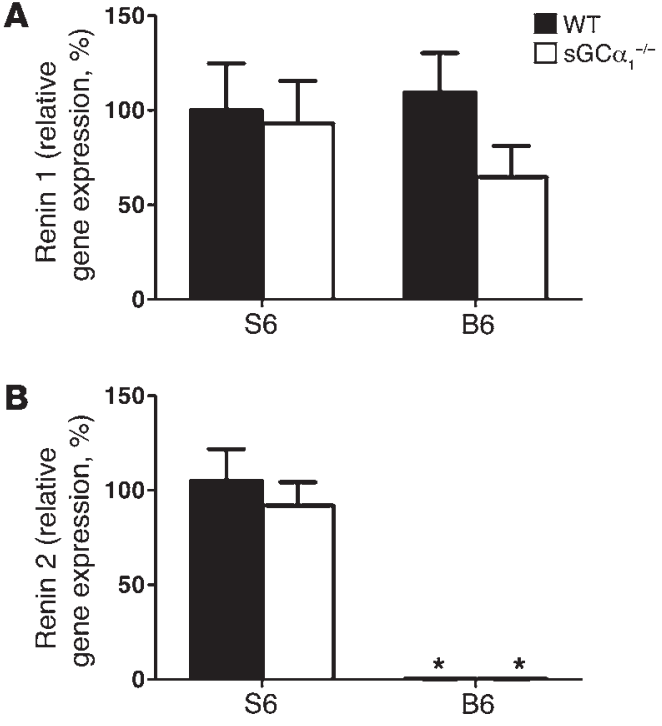

$\mathrm{sGCa}{ }^{-/-}$mice and suggest that the effect size of $\mathrm{Hsgcq}$ on blood pressure is approximately $11 \mathrm{mmHg}$.

The strain-specific bypertension in $\mathrm{SGCO}_{1^{-1-}}$ mice is associated with increased activity of the RAAS. To test whether the genetic background affected the RAAS, we measured plasma Ang II and plasma aldosterone levels in male $\mathrm{WT}^{\mathrm{B} 6}, \mathrm{sGC}_{1}{ }^{-/-\mathrm{B} 6}, \mathrm{WT}^{\mathrm{S} 6}$, and $\mathrm{sGC} \alpha_{1}^{-/-\mathrm{S} 6}$ mice. Plasma Ang II levels were similar in $\mathrm{WT}$ and $\mathrm{sGC} \alpha_{1}^{-/-}$mice on either the $\mathrm{B} 6$ or $\mathrm{S} 6$ background but were higher in $\mathrm{S} 6$ mice than in B6 mice (Figure 5A), confirming the existence of strain-specific differences in the RAAS. Plasma aldosterone levels did not differ in $\mathrm{WT}^{\mathrm{B} 6}$ and $\mathrm{sGC \alpha _{1 }}{ }^{-/-\mathrm{B} 6}$ mice (Figure $5 \mathrm{~B}$ ). However, plasma aldosterone levels were greater in $\mathrm{SGC}_{1}{ }^{-/-\mathrm{S} 6}$ than in $\mathrm{WT}^{\mathrm{S} 6}$ mice (Figure 5B). Expression levels of aldosterone synthase (cytochrome P450, family 11 , subfamily b, polypeptide 2 , or CYP11B2) in adrenal glands did not differ between $\mathrm{SGC}_{1}^{-/-\mathrm{B} 6}$ and $\mathrm{WT}^{\mathrm{B} 6}$ mice but were higher in $\mathrm{sGCa}_{1}{ }^{-/-\mathrm{S} 6}$ than in $\mathrm{WT}^{\mathrm{S} 6}$ mice (Supplemental Figure 6). Consistent with the observed hyperaldosteronism, plasma $\mathrm{K}^{+}$levels were lower and $\mathrm{Na}^{+}$levels were higher in $\mathrm{sGCa}_{1}{ }^{-/-\mathrm{S} 6}$ mice than in $\mathrm{WT}^{\mathrm{S} 6}$ mice (Table 1).

To further determine the contribution of the increased activity of the RAAS to the elevated blood pressure associated with sGC $\alpha_{1}$ deficiency, we treated male $\mathrm{WT}^{\mathrm{s} 6}$ and sGC $\alpha_{1}{ }^{-/-\mathrm{S} 6}$ mice with the clinically used renin inhibitor aliskiren, which is available for oral administration. Aliskiren did not alter blood pressure in male $\mathrm{WT}^{\mathrm{S} 6}$ mice but normalized blood pressure in male $\mathrm{SGC}_{1}{ }^{-/ \mathrm{S} 6}$ mice (Figure 6A). Similarly, the aldosterone antagonist spironolactone did not alter blood pressure in male $\mathrm{WT}^{\mathrm{S} 6}$ mice but normalized blood pressure in male sGC $\alpha_{1}^{-/-\mathrm{S} 6}$ mice (Figure $6 \mathrm{~B}$ ). No change in blood pressure was detected in either $\mathrm{WT}^{\mathrm{B} 6}$ or $\mathrm{sGC}_{1}{ }^{-/-\mathrm{B} 6}$ mice treated with the same dose of spironolactone (Supplemental Figure 7). Furthermore, the Ang II type 1 receptor (AT1) antagonist losartan decreased blood pressure more in male $\mathrm{SGC}_{1}{ }^{-/ \mathrm{S} 6}$ mice than in $\mathrm{WT}^{\mathrm{S} 6}$ mice (Supplemental Figure 8). Together, these data suggest that increased activity of the RAAS contributes to the hypertension associated with sGC $\alpha_{1}$ deficiency in $\mathrm{S} 6$ mice.

Normal glomerular filtration rate but decreased $\mathrm{K}^{+}$excretion in $\mathrm{s} \mathrm{GCO}_{1} \mathrm{C}^{-1-}$ mice. To test whether increased RAAS activity resulted in hypertension via an effect on renal function, we performed renal clearance studies in male $\mathrm{WT}^{\mathrm{s} 6}$ and $\mathrm{sGC}_{1}^{-/-\mathrm{s} 6}$ mice. While absolute $\left(\mathrm{E}_{\mathrm{Na}}\right)$

\section{Figure 3}

S6 mice express two renin isoforms, while $\mathrm{B} 6$ mice express one renin isoform. mRNAs encoding renin $1(\mathbf{A})$ and renin 2 (B) were measured via qRT-PCR in kidneys of male WT and $\mathrm{SGC} \alpha_{1}{ }^{-1-}$ mice on the $\mathrm{S} 6$ or B6 genetic background. $n=10-15 /$ group. No significant differences in renin 1 mRNA levels were found between WT and $s G C \alpha_{1}{ }^{-l-}$ mice on either background. mRNA levels of renin 2 were similar in WT and $\mathrm{sGC} \alpha_{1}{ }^{-1-}$ mice on the $\mathrm{S} 6$ genetic background, and were undetectable in WT and $\mathrm{SGC} \alpha_{1}^{-/-}$mice on the $\mathrm{B} 6$ genetic background. ${ }^{*} P<0.001$ versus $\mathrm{S} 6$. and fractional $\left(\mathrm{FE}_{\mathrm{Na}}\right)$ urinary sodium excretion were similar in $\mathrm{sGCa}_{1}^{-/-\mathrm{s} 6}$ mice and in WT $\mathrm{WT}^{\mathrm{s} 6}$ mice, absolute $\left(\mathrm{E}_{\mathrm{K}}\right)$ and fractional $\left(\mathrm{FE}_{\mathrm{K}}\right)$ urinary potassium excretion were lower in $\mathrm{sGC}_{1}{ }^{-/-\mathrm{s} 6}$ mice than in $\mathrm{WT}^{\mathrm{S} 6}$ mice. However, urinary volume and glomerular filtration rate (GFR), both corrected for body weight, were similar in $\mathrm{WT}^{\mathrm{S} 6}$ and $\mathrm{sGCa}_{1}{ }^{-/ \mathrm{S} 6}$ mice (Table 1 ). The lower body weight in $\mathrm{sGC}_{1}{ }^{-/ \mathrm{S} 6}$ mice compared with $\mathrm{WT}^{\mathrm{S} 6}$ mice may be secondary to the mild gastrointestinal dysfunction observed in $\mathrm{sGC}_{1}{ }^{-/-\mathrm{S} 6}$ mice (26). Together with the observation that blood urea nitrogen (BUN) levels were not higher in $\mathrm{sGCa}_{1}^{-/-\mathrm{S} 6}$ mice than in $\mathrm{WT}^{\mathrm{S} 6}$ mice, these findings argue against a central role for renal dysfunction in the hypertension observed in $\mathrm{sGC}_{1}{ }^{-/-\mathrm{S} 6}$ mice.

Activity of the RAAS modulates endothelium-dependent vascular reactivity. We previously reported that vascular smooth muscle relaxation in response to endothelium-derived $\mathrm{NO}$ was severely attenuated in aortic and femoral rings isolated from $\mathrm{sGC}_{1}{ }^{-/-\mathrm{s} 6}$ mice (19). In an independent study, the ability of acetylcholine to induce vasorelaxation in isolated carotid arteries was attenuated in $\mathrm{sGC}_{1}{ }^{-/-\mathrm{B} 6}$ mice (27). In the current study, we tested the hypothesis that differences in vascular reactivity between $\mathrm{sGC}_{1}{ }^{-/-}$mice on the $\mathrm{B} 6$ and $\mathrm{S} 6$ backgrounds contribute to the observed strain-related difference

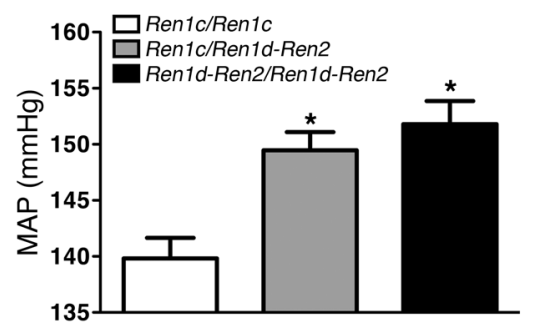

\section{Figure 4}

Mice homozygous or heterozygous for the 12956 renin locus have higher blood pressure than mice homozygous for the $\mathrm{B} 6$ renin locus. MAP was measured invasively in anesthetized male $\mathrm{SGC} \alpha_{1}{ }^{-1-\mathrm{F} 2}$ mice homozygous for renin 1c (Ren1c/Ren1c = the B6 locus, $n=76)$, homozygous for renin $1 \mathrm{~d} /$ renin 2 (Ren1d-Ren2/Ren1d-Ren2 = the S6 locus, $n=73)$, or heterozygous for both loci (Ren1c/Ren1d-Ren2; $n=135)$. ${ }^{\star} P<0.001$ versus all other groups by 1 -way ANOVA. 


\section{A}
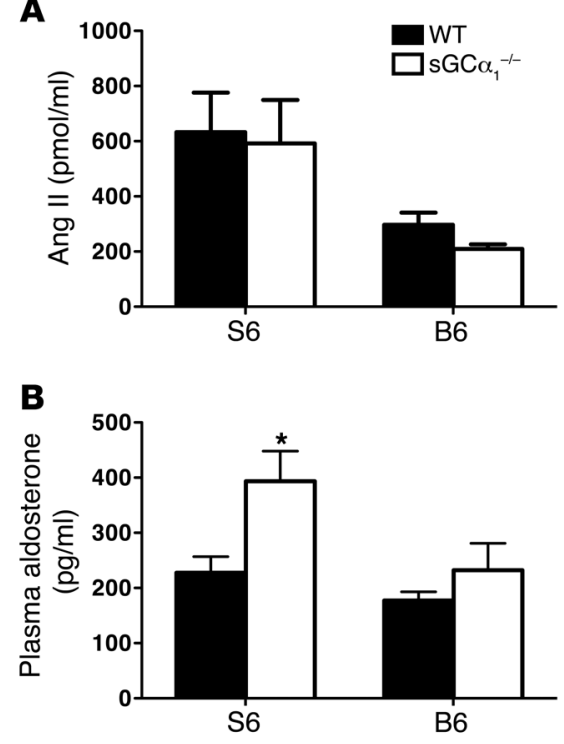

in blood pressure. We compared vascular relaxation in response to acetylcholine in isolated pre-constricted aortic rings from male WT and $\mathrm{sGC} \mathrm{C}_{1}^{-/-}$mice on both the B6 and $\mathrm{S} 6$ backgrounds. Acetylcholine-induced vascular relaxation was impaired to a greater

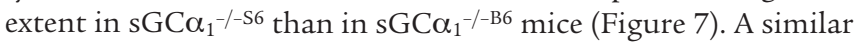
result was obtained in mesenteric arteries (Supplemental Figure 9). These findings suggest that the decreased sensitivity of the vasculature to endothelium-dependent relaxation may contribute to the strain-specific hypertension in $\mathrm{sGCa}_{1}{ }^{-/}$mice.

To investigate whether increased RAAS signaling in $\mathrm{sGC}_{1}{ }^{-/-\mathrm{S} 6}$ mice reduces the ability of the vasculature to vasorelax, we studied the responsiveness to acetylcholine of aortic rings isolated from mice treated for 3 weeks with the angiotensin-converting enzyme (ACE) inhibitor enalapril. Importantly, after prolonged inhibition of RAAS signaling with enalapril, the ability of acetylcholine to relax aortic rings isolated from $\mathrm{sGC} \alpha_{1}{ }^{-/-\mathrm{S} 6}$ mice no longer differed from that observed in aortic rings isolated from $\mathrm{sGC} \alpha_{1}^{-/-B 6}$ mice (Figure 7). Treatment with enalapril also tended to improve the ability of acetylcholine to induce vasorelaxation in $\mathrm{sGCa}_{1}^{-/-\mathrm{B} 6}$ mice ( $P=0.069$ vs. $\mathrm{sGC} \alpha_{1}{ }^{-/-\mathrm{B} 6}$ mice that did not receive enalapril). Taken together, these results suggest that activity of the RAAS has a direct impact on endothelium-dependent vasorelaxation. Increased RAAS activity may therefore be, at least in part, responsible for the greater impairment of vascular relaxation in $\mathrm{sGC} \alpha_{1}^{-/-\mathrm{S} 6}$ than in $\mathrm{sGC} \alpha_{1}^{-/-\mathrm{B} 6}$ mice, thereby contributing to the hypertension observed in $\mathrm{sGC} \alpha_{1}{ }^{-/-\mathrm{S} 6}$ mice.

\section{Discussion}

Animal and epidemiological studies have demonstrated that genetic factors contribute to the pathogenesis of essential hypertension. Recent advances in performing and interpreting GWAS and candidate gene-association studies have allowed the identification of common genetic variants that influence blood pressure $(3,5-8,28)$. Genetic variation in both cGMP signaling, including in the genes encoding the $\mathrm{sGC} \alpha_{1} \beta_{1}$ isoform (7), and RAAS signaling pathways have been implicated in the regulation of blood pressure in both human (5-8) and animal (29-32) models of hypertension. Here, we used both a nonbiased genetic approach (linkage analysis) and a targeted approach (investigating a specific molecu-

\section{Figure 5}

Activity of the RAAS is increased in $\mathrm{SGC} \alpha_{1}^{-/-}$mice on the $\mathrm{S} 6$ background. (A) Ang II in plasma of male WT and $\mathrm{sGC}_{\alpha_{1}}{ }^{--}$mice on the B6 and on the S6 genetic background. $n=6-9$. $P<0.01$ for $\mathrm{S} 6$ versus B6 by 2-way ANOVA. (B) Plasma aldosterone levels in male WT and sGC $\alpha_{1}{ }^{-1-}$ mice on the $\mathrm{B} 6$ and on the $\mathrm{S} 6$ genetic background. $n=11$ for all groups. ${ }^{*} P<0.05$ versus WTS6 by 2 -way ANOVA.

lar pathway, i.e., RAAS) to identify renin as a candidate modifier gene for blood pressure in a setting of impaired NO/cGMP signaling. In addition, our findings suggest that a vascular, rather than a renal, effect of increased RAAS activity underlies the hypertension observed in $\mathrm{SGCa}_{1}^{-/-\mathrm{S} 6}$ mice.

Variation in the genetic makeup of laboratory mouse strains affects the cardiovascular phenotype of those strains $(33,34)$. For example, ACE2 deficiency was associated with a modest increase in blood pressure in mice on the B6 background but had no effect on blood pressure in S6 mice (35). Inhibition of NO synthase had

\section{Table 1}

Renal function is similar in $\mathrm{WT}^{\mathrm{S} 6}$ and $\mathrm{sGC} \alpha_{1}^{-/-\mathrm{S} 6}$ mice

\begin{tabular}{|c|c|c|c|}
\hline & WT & $\mathbf{s G C} \alpha_{1}{ }^{-/-}$ & $P$ value \\
\hline \multicolumn{4}{|l|}{ Renal clearance studies } \\
\hline$n$ & 8 & 12 & \\
\hline Age (wk) & $35 \pm 1$ & $36 \pm 1$ & 0.1405 \\
\hline BW $(g)$ & $35 \pm 1$ & $28 \pm 1$ & 0.0001 \\
\hline UV/BW $(\mu \mathrm{l} / \mathrm{min} / 100 \mathrm{~g})$ & $3.6 \pm 0.4$ & $3.2 \pm 0.3$ & 0.3316 \\
\hline GFR/BW (ml/min/100 g) & $0.68 \pm 0.08$ & $0.70 \pm 0.06$ & 0.8762 \\
\hline $\mathrm{E}_{\mathrm{Na}}(\mu \mathrm{Eq} / \mathrm{min} / 100 \mathrm{~g} \mathrm{BW})$ & $0.69 \pm 0.12$ & $0.58 \pm 0.06$ & 0.4036 \\
\hline $\mathrm{E}_{\mathrm{K}}(\mu \mathrm{Eq} / \mathrm{min} / 100 \mathrm{~g} \mathrm{BW})$ & $0.55 \pm 0.07$ & $0.31 \pm 0.05$ & 0.0086 \\
\hline $\mathrm{FE}_{\mathrm{Na}}(\%)$ & $0.72 \pm 0.14$ & $0.60 \pm 0.05$ & 0.3451 \\
\hline $\mathrm{FE}_{\mathrm{K}}(\%)$ & $19 \pm 2$ & $12 \pm 2$ & 0.0316 \\
\hline $\mathrm{U}_{\mathrm{Na}}(\mu \mathrm{Eq})$ & $193 \pm 27$ & $188 \pm 12$ & 0.8303 \\
\hline$U_{K}(\mu \mathrm{Eq})$ & $162 \pm 18$ & $107 \pm 17$ & 0.0432 \\
\hline $\mathrm{MAP}(\mathrm{mmHg})$ & $127 \pm 3$ & $145 \pm 3$ & 0.0005 \\
\hline \multicolumn{4}{|l|}{ Blood analysis } \\
\hline$n$ & 15 & 13 & \\
\hline Age (wk) & $10 \pm 1$ & $10 \pm 1$ & 0.8910 \\
\hline BW (g) & $27 \pm 1$ & $22 \pm 1$ & 0.0007 \\
\hline $\mathrm{P}_{\mathrm{NA}}(\mathrm{mmol} / \mathrm{l})$ & $144 \pm 0$ & $146 \pm 1$ & 0.0201 \\
\hline $\mathrm{P}_{\mathrm{K}}(\mathrm{mmol} / \mathrm{l})$ & $5 \pm 1$ & $4 \pm 1$ & 0.0035 \\
\hline BUN (mg/dl) & $33 \pm 5$ & $26 \pm 5$ & 0.0003 \\
\hline
\end{tabular}

Values are mean \pm SEM. UV, urinary volume; $\mathrm{U}_{\mathrm{Na}}$, urinary sodium concentration; $U_{K}$, urinary potassium concentration; $P_{N a}$, plasma sodium concentration; $P_{K}$, plasma potassium concentration. Absolute $P$ values from Student's $t$ test are shown. 

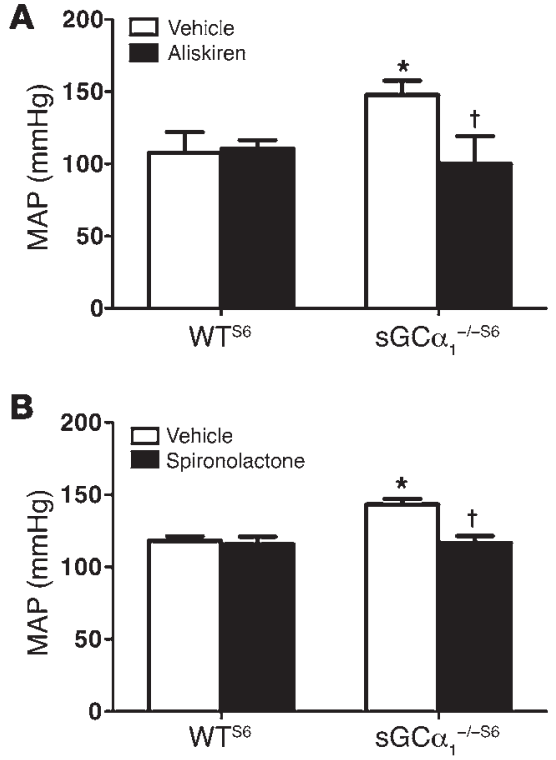

a more profound effect on renal blood flow in S6 mice than in B6 mice (36), blood pressure was consistently higher in S6 than in B6 mice (36), and S6 mice were found to be more susceptible to the development of hypertension and kidney injury after subtotal nephrectomy than were B6 mice (37). Several reports demonstrated that linkage studies in rodents represent a feasible and powerful approach to identify genetic loci and/or candidate modifier genes involved in the etiology of hypertension (31,37-40). In the current study, we sought to identify genetic variants that modify blood pressure in $\mathrm{sGC} \mathrm{G}_{1}^{-/-}$mice by taking advantage of the observation that male $\mathrm{sGC} \alpha_{1}{ }^{-/-\mathrm{S} 6}$ but not $\mathrm{sGC} \alpha_{1}^{-/-\mathrm{B} 6}$ mice develop hypertension $(18,21)$. Using a linkage analysis approach in $284 \mathrm{sGC \alpha}_{1}^{-/-\mathrm{F} 2}$ mice, we identified a genomic locus $(H s g c q)$ on chromosome 1 (covering $\approx 40 \mathrm{Mb}$ ) that was associated with hypertension in $\mathrm{sGC}_{1}{ }^{-/-}$mice. This QTL (located on Mus musculus 1-E4) is syntenic to known hypertension QTLs in rats (Rattus norvegicus 13q13) and humans (Homo sapiens 1q32; Supplemental Figure 10). Importantly, variants of one of the genes located in this region, renin, were previously identified to be associated with blood pressure in rats (41, $42)$ and humans $(43,44)$. Additional research will be required to identify other blood pressure-modifying genes that contribute to the hypertension in $\mathrm{sGC}_{1}{ }^{-/-\mathrm{S} 6}$ mice (e.g., in the other loci identified in our linkage analysis [on chromosomes 4 and 9]).

In the Hsgcq QTL identified in our linkage study, renin represents a strong biological candidate modifier gene of blood pressure. Renin is a key enzyme in the RAAS that is responsible for the control of fluid homeostasis and blood pressure. It is well established that inappropriate activation of the RAAS is an important contributor to the pathogenesis of hypertension (45). Importantly, genetic linkage of the renin locus with hypertension was previously identified in large population studies (44). Human and rat genomes contain a single gene for renin. Mice, however, display two alternative genotypes at the renin locus, with some inbred mouse strains (e.g., B6) having only a single renin gene designated renin 1c, while others (e.g., S6) possess two closely linked renin genes on chromosome 1 termed renin $1 \mathrm{~d}$ and renin 2 (23-25). Overexpression of murine renin 2 in rats resulted in hypertension (46) that was attributed to RAAS-dependent blunting of NO/

\section{Figure 6}

RAAS inhibition normalizes blood pressure in $\mathrm{sGC} \alpha_{1}^{-1-S 6}$ mice. (A) MAP, measured invasively in anesthetized male WT and $\mathrm{sGC} \alpha_{1}^{-/-}$ mice on the $129 S 6$ background treated with vehicle $(n=8$ and 6 , respectively) or aliskiren ( $n=5$ and 8 , respectively). ${ }^{\star} P<0.001$ versus WT vehicle; ${ }^{\dagger} P<0.001$ versus $\mathrm{SGC} \alpha_{1}{ }^{-1-}$ vehicle. (B) MAP in male WT and $\mathrm{sGC} \alpha_{1}{ }^{-/}$mice on the $129 \mathrm{~S} 6$ background treated with vehicle ( $n=5$ and 8, respectively) or spironolactone ( $n=5$ and 12, respectively). ${ }^{*} P<0.01$ versus WT vehicle; ${ }^{\dagger} P<0.001$ versus $\mathrm{sGC} \alpha_{1}{ }^{-1-}$ vehicle.

sGC-mediated vasorelaxation (47). In addition to the previously reported duplication of the renin gene in S6 mice, multiple genetic differences were identified between renin $1 \mathrm{c}$ and renin $1 \mathrm{~d}$, including 5 missense mutations. Whether the duplication and/or the renin 1 missense mutations contribute to the strain-specific and RAAS-dependent hypertension in $\mathrm{sGC}_{1}{ }^{-/-\mathrm{s} 6}$ mice remains to be determined. It is well known that the mechanism of activation of pro-renin is species-specific (48) and that the active site of human renin is unique (49). Based on the extensive differences in genomic, cDNA, and amino acid sequence between the murine and human renin 1 genes (see Supplemental Figure 11 for the amino acid alignment between human renin 1 and mouse renin 1c), it is

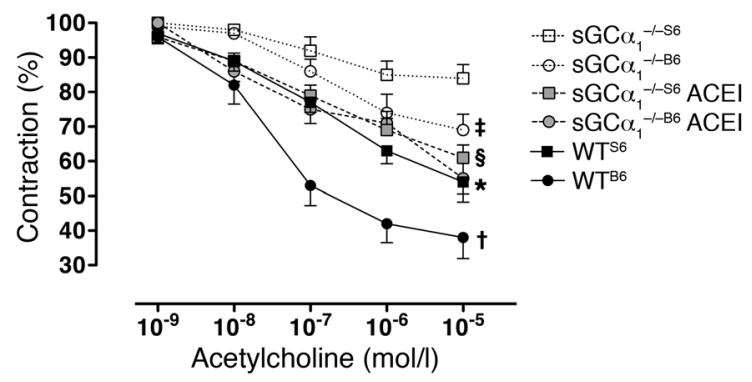

\section{Figure 7}

The strain-specific hypertension in $\mathrm{sGC} \alpha_{1}^{-1-}$ mice is associated with greater impairment of vascular reactivity in $\mathrm{sGC}_{\alpha_{1}}{ }^{-1-\mathrm{S} 6}$ mice than in $\mathrm{sGC} \alpha_{1}{ }^{-1-\mathrm{B} 6}$ mice. Acetylcholine-induced relaxation was studied in phenylephrine-precontracted aortic rings from male wild-type (black symbols, solid line) and sGC $\alpha_{1}$-deficient mice (sGC $\left.\alpha_{1}{ }^{--}\right)$on a B6 (circles) or S6 (squares) genetic background. SGC $\alpha_{1}^{-1-}$ mice were either pretreated (gray symbols, dashed line) or not (white symbols, dotted line) with the ACE inhibitor (ACEI) enalapril. Acetylcholine-induced vascular relaxation was impaired to a greater extent in $\mathrm{SGC}_{\alpha_{1}}{ }^{-/-\mathrm{S} 6}$ than in $\mathrm{SGC} \alpha_{1}{ }^{-1-B 6}$ mice. In vivo pretreatment with enalapril restored vascular reactivity in $\mathrm{sGC} \alpha_{1}^{-l-\mathrm{S} 6}$ to levels observed in $\mathrm{sGC} \alpha_{1}^{-l-\mathrm{B} 6}$ mice. $n=9,8,9,4,10$, and 12 for $\mathrm{sGC} \alpha_{1}{ }^{-/-\mathrm{S} 6}, \mathrm{sGC} \alpha_{1}{ }^{-/-\mathrm{B} 6}, \mathrm{sGC} \alpha_{1}{ }^{-/-\mathrm{S} 6} \mathrm{ACEl}$, $\mathrm{SGC}{ }^{-1-\mathrm{B} 6} \mathrm{ACEI}, \mathrm{WT} \mathrm{T}^{\mathrm{S}}$, and $\mathrm{WT}^{\mathrm{B} 6}$, respectively. ${ }^{*} P<0.001$ versus sGC $\alpha_{1}{ }^{-/-\mathrm{S} 6} ;{ }^{\dagger} P<0.01$ versus $\mathrm{sGC} \alpha_{1}^{-/-\mathrm{B} 6} ; \ddagger P<0.05$ versus $\mathrm{sGC} \alpha_{1}^{-/-\mathrm{S} 6}$; $\S P<0.01$ versus $\mathrm{sGC} \alpha_{1}^{-/-\mathrm{S} 6}$. 
unlikely that identification of the causative mutation (or mutations) in the murine renin genes would be directly translatable to the human renin gene. However, the finding that the combination of altered RAAS signaling (regardless of the causative mutation) and impaired NO/cGMP signaling results in hypertension in mice is translatable to the human condition. Both increased RAAS activity (45) and impaired NO/cGMP signaling (associated with, for example, endothelial dysfunction [ref. 50] and oxidation of sGC [ref. 51]) can increase blood pressure in humans. Genetic variants in the renin gene $(43,44)$ and in a locus encoding the sGC $\alpha_{1}$ and sGC $\beta_{1}$ subunits ( 7 ) were found to be associated with blood pressure, highlighting the relevance of renin and sGC in regulating blood pressure in humans.

To confirm that renin is a modifier for blood pressure in a setting of impaired NO/cGMP signaling, we compared the activity of the RAAS in S6 and B6 mice. The observation that plasma Ang II levels were higher in S6 mice than in B6 mice confirms the existence of strain-specific differences in activity of the RAAS. It is likely that the observation that Ang II levels were higher in S6 than in $\mathrm{B} 6$ mice, regardless of their sGC $\alpha_{1}$ genotype, is a consequence of the difference in renin genotype, and that renin acts as a modifier of blood pressure in both $\mathrm{sGC}_{1^{-/-}}$and WT mice. Although blood pressures were higher in $\mathrm{WT}^{\mathrm{s} 6}$ and $\mathrm{sGC} \alpha_{1}^{-/-\mathrm{S} 6}$ mice (expressing renin $1 \mathrm{~d}$ and renin 2 ) than in $\mathrm{WT}^{\mathrm{B} 6}$ and $\mathrm{sGC} \alpha_{1}^{-/-\mathrm{B} 6}$ mice (expressing renin 1c), respectively, our results suggest that the blood pressure-modifying effect of renin is more apparent when NO/cGMP signaling is impaired (e.g., in $\mathrm{sGC}_{1}{ }^{-/-}$mice) than when $\mathrm{NO} / \mathrm{cGMP}$ signaling is intact (e.g., in WT mice).

Plasma aldosterone and adrenal expression of the aldosterone synthase CYP11B2 were higher in hypertensive $\mathrm{sGC}_{1}{ }^{-/-\mathrm{s} 6}$ mice than in normotensive $\mathrm{WT}^{\mathrm{S} 6}$ mice. This was an unexpected finding, since an increase in blood pressure would be expected to lead to a homeostatic reduction in RAAS activity due to the renal baroreceptor mechanism (52). It is important to note that a higher adrenal expression level of CYP11B2 in $\mathrm{sGC}_{1}{ }^{-/-\mathrm{S} 6}$ than in $\mathrm{WT}^{56}$ mice does not provide additional evidence that renin is a modifier gene for blood pressure in $\mathrm{sGC} \alpha_{1}^{-/-\mathrm{S} 6}$ mice, nor does it indicate that Cyp11b2 (located on chromosome $15 \mathrm{qD} 3$ ) is a modifier gene. Instead, higher adrenal CYP11B2 expression levels in $\mathrm{sGC}_{1}{ }^{-/-\mathrm{S} 6}$ than in $\mathrm{WT}^{\mathrm{S} 6}$ mice suggest that NO/cGMP signaling modulates RAAS activity at the level of Cyp11b2 gene expression. Furthermore, increased adrenal CYP11B2 expression levels likely contribute to the elevated plasma aldosterone levels observed in $\mathrm{sGC} \alpha_{1}^{-/-\mathrm{S} 6}$ mice.

Blocking the RAAS, by inhibiting renin activity with aliskiren or aldosterone receptor signaling with spironolactone, at doses that did not affect blood pressure in WT mice and $\mathrm{sGC} \alpha_{1}{ }^{-/-B 6}$ mice, normalized blood pressure in $\mathrm{sGC}_{1}{ }^{-/-\mathrm{S} 6}$ mice. Furthermore, acute administration of the AT1 antagonist losartan decreased blood pressure to a greater extent in $\mathrm{sGC}_{1}{ }^{-/-\mathrm{S} 6}$ mice than in $\mathrm{WT}^{\mathrm{S} 6}$ mice. The greater sensitivity of $\mathrm{sGC \alpha}_{1}{ }^{-/ \mathrm{S} 6}$ mice to the blood pressure-lowering effects of aliskiren, spironolactone, and losartan suggests that increased activity of the RAAS contributes to the hypertension associated with sGC $\alpha_{1}$ deficiency in S6 mice. It is conceivable that both genetics (renin genotype) and interactions between the NO/cGMP signaling and the RAAS (altered gene expression of Cyp11b2) contribute to the hypertension observed in $\mathrm{sGC} \mathrm{C}_{1}^{-/-\mathrm{S} 6}$ mice. Additional characterization of the RAAS, both renal and extrarenal, is required to fundamentally understand the role of altered RAAS signaling in the hypertension associated with impaired NO/cGMP signaling.
Many studies have established an important role for the kidney in the development of high blood pressure (9). We did not find evidence of overt renal dysfunction in hypertensive $\mathrm{SGC}_{1^{-/-S 6}}$ mice. BUN levels were not increased in $\mathrm{sGC}_{1}{ }^{-/ \mathrm{S} 6}$ mice, and GFR was similar in $\mathrm{WT}^{\mathrm{S} 6}$ and $\mathrm{sGC}_{1}{ }^{-/-\mathrm{S} 6}$ mice. The mechanisms underlying the lower absolute and fractional urinary potassium excretion in $\mathrm{sGC}_{1}{ }^{-/-\mathrm{S} 6}$ mice than in $\mathrm{WT}^{\mathrm{s} 6}$ mice remain to be determined. As would be expected, higher plasma aldosterone levels in $\mathrm{sGC}_{1}^{-/-\mathrm{s} 6}$ than in $\mathrm{WT}^{\mathrm{S} 6}$ mice were associated with lower plasma $\mathrm{K}^{+}$levels and higher plasma $\mathrm{Na}^{+}$levels in the former. It is possible that kidneys in $\mathrm{sGC} \alpha_{1}^{-/-\mathrm{S} 6}$ mice adapt to decreased $\mathrm{K}^{+}$levels by increasing reabsorption and/or reducing secretion of $\mathrm{K}^{+}$in an attempt to maintain homeostasis. Alternatively, the lower $\mathrm{K}^{+}$excretion in $\mathrm{sGC}_{1}{ }^{-/-\mathrm{S} 6}$ than in $\mathrm{WT}^{\mathrm{S} 6}$ mice may be due to reduced $\mathrm{K}^{+}$channel

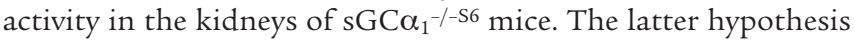
stems from the observation that $\mathrm{NO}$ and $\mathrm{cGMP}$ can stimulate the activity of apical small-conductance $\mathrm{K}^{+}\left(\mathrm{SK}^{+}\right)$and basolateral $\mathrm{K}^{+}$ channels, respectively $(53,54)$. Finally, we cannot exclude the possibility that reduced $\mathrm{K}^{+}$levels and excretion are attributable to gastrointestinal malabsorption, caused by abnormal gastric motility previously observed in $\mathrm{sGC} \alpha_{1}^{-/-\mathrm{S} 6}$ mice (26).

In the absence of apparent renal dysfunction, hypertension was previously reported to arise from primary vascular abnormalities (10). In cGMP-dependent protein kinase $1 \alpha$ mutant mice, for example, hypertension was observed in the setting of normal renal function and normal renal salt handing, but decreased vascular relaxation in response to a nitrovasodilator (11). We previously reported that both endothelium-dependent and endotheliumindependent vascular relaxation are attenuated in aortic and femoral artery rings isolated from $\mathrm{sGC}_{1}{ }^{-/-\mathrm{S} 6}$ mice (19) and in carotid arteries isolated from $\mathrm{sGC} \alpha_{1}^{-/-\mathrm{B} 6}$ mice (27). These findings highlighted the importance of $\mathrm{sGC} \alpha_{1} \beta_{1}$-derived $\mathrm{cGMP}$ in the relaxation of vascular smooth muscle by NO. In the current study, we observed that the ability of acetylcholine to induce vasorelaxation is impaired to a greater extent in $\mathrm{sGC}_{1}{ }^{-/-\mathrm{S} 6}$ than in $\mathrm{sGC}_{1}{ }^{-/-\mathrm{B} 6}$ mice, both in the aorta and in mesenteric arteries, suggesting that decreased vascular reactivity may contribute to the strain-specific hypertension in $\mathrm{sGC}_{1}{ }^{-/-}$mice. Similarly, greater impairment of endothelium-dependent relaxation in $\mathrm{WT}^{\mathrm{S} 6}$ mice than in $\mathrm{WT}^{\mathrm{B} 6}$ may contribute to the higher blood pressure observed in $\mathrm{WT}^{\mathrm{S} 6}$ mice than in $\mathrm{WT}^{\mathrm{B} 6}$ mice (36).

Surprisingly, in vivo inhibition of RAAS signaling with the ACE inhibitor enalapril restored vascular reactivity in $\mathrm{sGC}_{1}{ }^{-/-\mathrm{S} 6}$ mice to the level observed in $\mathrm{sGC} \alpha_{1}^{-/-\mathrm{B} 6}$ mice that were either pretreated with enalapril or not pretreated with enalapril. Together, these results suggest that differences in RAAS activity can impact the ability of the vasculature to relax in response to acetylcholine and raise the possibility that $H s g c q$ influences blood pressure in the context of sGC $\alpha$-deficiency by directly modulating endotheliumdependent vasorelaxation. To unequivocally demonstrate that Hsgcq modulates the ability of acetylcholine to induce vascular relaxation, vascular reactivity needs to be assessed in arteries isolated from $\mathrm{sGC}_{1}^{-/-\mathrm{F} 2}$ mice.

Multiple studies have demonstrated that extrarenal (including vascular) RAAS signaling can modulate blood pressure $(55,56)$. Renin (57), aldosterone (58), and aldosterone receptors (59) were previously shown to be expressed in vascular tissue (60). In addition, aldosterone itself was reported to have a direct vasoconstrictive effect $(61,62)$. However, the exact function of the vascular RAAS remains elusive (60). Our model of RAAS-dependent hyper- 
tension associated with sGC $\alpha_{1}$ deficiency may allow for further elucidation of the role of the vascular RAAS in regulation of vascular tone. One potential mechanism by which increased RAAS signaling may affect vascular function is an aldosterone-mediated increase in oxidative stress (55). The resulting oxidative modification of the Cys 122 residue on sGC $\beta_{1}$ would convert sGC $\alpha_{2} \beta_{1}$ in sGC $\alpha_{1}{ }^{-/-}$mice to an NO-insensitive state (55). Activity of sGC $\alpha_{2} \beta_{1}$ was previously shown to contribute to the vasorelaxing effect of NO $(15,18,19)$. Decreased activity of sGC $\alpha_{2} \beta_{1}$ would further disrupt normal vasodilatory signaling in vascular smooth muscle. However, whether increased activity of the RAAS associated with sGC $\alpha_{1}$ deficiency results in subsequent oxidation and inactivation of sGC $\alpha_{2} \beta_{1}$ remains to be determined. Additional studies are required to test whether $\mathrm{NO}$-independent $\mathrm{SGC}$ activators that can activate oxidized sGC $(63,64)$ are able to rescue the vascular dysfunction seen in $\mathrm{sGC}_{1}{ }^{-/-\mathrm{S} 6}$ mice.

We previously reported that hypertension in $\mathrm{sGC} \alpha_{1}^{-/-\mathrm{S} 6}$ mice was male specific and testosterone dependent (18). It is conceivable that androgens modulate RAAS activity, thereby affecting blood pressure in a sex-specific manner and contributing to the hypertension observed in $\mathrm{SGCa}_{1}^{-/-\mathrm{S} 6}$ mice (65). For example, renin 2 was reported to be an androgen-responsive gene $(66,67)$. Moreover, overexpression of murine renin 2 in rats resulted in testosteronedependent hypertension (68). Furthermore, the RAAS has been suggested to have a greater impact on blood pressure regulation in males than in females: knocking out the gene encoding ACE1 decreased blood pressure in male but not female mice (69), and in a large population study, genetic linkage of the ACE locus with hypertension was found in men but not in women (70). Precisely how testosterone interacts with the RAAS to modulate blood pressure in $\mathrm{sGC} \alpha_{1}^{-/-\mathrm{S} 6}$ mice remains to be investigated.

Associations between common gene variants and hypertension offer mechanistic insights into the regulation of blood pressure and may help in the development of novel intervention strategies to prevent and treat CVD. Improved knowledge of interactions between signaling pathways previously identified to regulate blood pressure will impact our understanding of the etiology of essential hypertension. For example, the observation that increased activity of the RAAS contributes to the pathogenesis of hypertension associated with impaired NO/cGMP signaling may have clinical implications. Both impaired NO/cGMP signaling $(14,15,18)$ and increased activity of the RAAS (9) were reported to be involved in the development of hypertension. Therefore, a combination of pharmacological inhibition of the RAAS and pharmacological stimulation of sGC may offer novel strategies to treat hypertension $(71,72)$, especially in settings where use of classical NO donor compounds is problematic because of the development of tolerance (73).

In conclusion, the identification of a locus on mouse chromosome 1 that contains the renin gene(s) and that modifies blood pressure in $\mathrm{sGCO}_{1}^{-/-}$mice, together with the observation that the strain-specific hypertension in $\mathrm{sGC \alpha}_{1}^{-/-}$mice is associated with increased activity of the RAAS, strongly suggests that activity of the RAAS modulates the susceptibility to hypertension in a setting of impaired NO/cGMP signaling. The finding that NO/cGMP signaling and RAAS signaling (two established pathways in the regulation of blood pressure in humans) interact, has great potential to advance our understanding of the etiology of human hypertension. Understanding the interaction of pathways that modulate blood pressure is particularly critical, given the multigenic pathogenesis of most forms of hypertension, and may help define genetically distinct subgroups of men and women with essential hypertension. Further elucidation of how interaction of NO/cGMP signaling and the RAAS affects cardiovascular function in mice is likely to impact the clinical development of sGC-activating compounds for treatment of CVDs (51) and may promote the search for new $\mathrm{sGC}$ isoform-specific agonists.

\section{Methods}

Generation and blood pressure measurement of $F_{2}$ offspring from an $s \mathrm{GC}_{1}^{-1-s 6} \times$ $s G C \alpha_{1}^{-1-B 6}$ intercross. Only male mice were studied. Generation of $\mathrm{sGC}_{1}{ }^{-/-\mathrm{S} 6}$ (generated on the $\mathrm{S} 6$ background) and $\mathrm{sGC}_{1}{ }^{-/-\mathrm{B} 6}$ mice (backcrossed 8 generations with $\mathrm{B} 6$ mice from The Jackson Laboratory) was described previously $(18,21)$. WT ${ }^{\mathrm{B} 6}$ and WT $\mathrm{T}^{\mathrm{S} 6}$ mice were purchased from The Jackson Laboratory and Taconic, respectively. Male sGC $\alpha_{1}^{-/-S 6}$ and female $\mathrm{sGC}_{1} \mathrm{~S}^{-/-\mathrm{B} 6}$ mice ( 4 breeding pairs) were crossed to yield $\mathrm{F}_{1}$ offspring. The $\mathrm{F}_{1}$ offspring were subsequently intercrossed ( 16 breeding pairs) to yield $F_{2}$ offspring. MAP was measured invasively in 284 male $\mathrm{F}_{2}$ offspring at 4 months of age, as previously described $(18,21)$. Briefly, mice were anesthetized by i.p. injection with ketamine $(100 \mathrm{mg} / \mathrm{kg})$, fentanyl $(50 \mathrm{mg} / \mathrm{kg})$, and pancuronium $(2 \mathrm{mg} / \mathrm{kg})$; intubated; and mechanically ventilated $\left(\mathrm{FiO}_{2}\right.$ of $1,10 \mu \mathrm{l} / \mathrm{g}$, 120 breaths per minute). A fluid-filled catheter was inserted into the left carotid artery for infusion of saline solution $(2 \mathrm{ml} / \mathrm{h})$ and for measurement of MAP. The reproducibility of the invasive hemodynamic technique described here was validated previously by measuring blood pressure in $\mathrm{WT}^{\mathrm{S} 6}$ and $\mathrm{sGCa}_{1}^{-/-\mathrm{S} 6}$ mice using radiotelemetry (in unrestrained, unanesthetized mice), invasive hemodynamics (in anesthetized mice), and tail-cuff (in restrained, unanesthetized mice) (18).

Genotyping. Genomic DNA was isolated from ear tissue of $284 \mathrm{sGC}_{1}{ }^{-/-\mathrm{F} 2}$ mice using a commercially available kit (DNeasy, QIAGEN). For genome scans, mice were genotyped using 120 B6-S6 informative SNPs covering the murine autosomes (average inter-marker spacing, 22.2 Mb; largest inter-marker gap, 54.6 Mb). All SNPs were assayed using Sequenom MasSARRAY iPLEX GOLD chemistry. Oligonucleotides were synthesized and subjected to quality control analysis by mass spectrometry at Integrated DNA Technologies. All SNPs were genotyped in multiplexed pools of up to 36 assays, designed by AssayDesigner v.3.1 software, starting with $10 \mathrm{ng}$ DNA per pool. Seven nanoliters of reaction were loaded onto each position of a 384-well SpectroCHIP preloaded with $7 \mathrm{nl}$ matrix (3-hydroxypicolinic acid). SpectroCHIPs were analyzed in automated mode by a MassArray MALDI-TOF Compact System 2 with a solid phase laser mass spectrometer (Bruker Daltonics). Variants were called by real-time SpectroCALLER algorithm and analyzed by SpectroTYPER v.4.0 software, and clusters were manually reviewed for validation of genotype calls. Poorly genotyped markers were removed prior to analysis. Subsequently, all 284 sGC $\alpha 1^{-/-\mathrm{F} 2}$ mice were genotyped using 28 SNPs spaced approximately $4 \mathrm{Mb}$ apart and spanning a region on chromosome 1 extending from $30 \mathrm{Mb}$ to $173 \mathrm{Mb}$. Reported genetic map positions for the markers were retrieved from the SNP database (build 36.1) of the National Center for Biotechnology Information (NCBI).

Linkage and sequence analysis. As the phenotype appears normally distributed, parametric linkage analysis was performed using MAPMAKER/QTL (74) to identify QTLs associated with blood pressure. For an $\mathrm{F}_{2}$ intercross, a lod of approximately 2.8 is considered "suggestive" (expected to be seen by chance once per genome scan), a lod of approximately 4.3 is considered "significant" (with a genome-wide corrected $P=0.05$, a score expected to be seen by chance only once per 20 genome scans), and a lod of approximately 6.1 is considered "highly significant" (genome-wide corrected $P=0.001)(75)$. A region within 1.5 lod score units of the maximum lod was used to represent the $95 \%$ interval for a strong QTL (76). The genome-wide scans were plotted with the use of the J/qtl mapping pro- 
gram (version 0.8) (http://churchill.jax.org/software/jqtl.shtml). Heritability was calculated as $\left(\mathrm{F}_{2}\right.$ variance - weighted average of parental variance and $F_{1}$ variance) $/ F_{2}$ variance. Genomic, cDNA, and amino acid sequences for the $\mathrm{B} 6$ and $\mathrm{S} 6$ renin loci were obtained from publicly available databases (ENSEMBL and NCBI, respectively) and were aligned using MegAlign software (DNASTAR).

Measurement of gene expression. Total RNA was extracted from whole kidneys or adrenal glands harvested from 8- to 16-week-old mice using TRIzol reagent (Invitrogen), and cDNA was synthesized using Maloney's murine leukemia virus reverse transcriptase (Promega). Renin 1c, renin 1d, renin 2, CYP11B2, and 18S rRNA transcript levels were measured by real-time PCR using the SYBR or TaqMan universal PCR master mix (Applied Biosystems) in a Mastercycler ep realplex 2 (Eppendorf). Primers were designed for renin 1 (detecting renin $1 \mathrm{c}$ and renin $1 \mathrm{~d}$; $5^{\prime}$-CTCTCTGGGCACTCTTGTTGC-3' and 5'-GGGAGGTAAGATTGGTCAAGGA-3'), CYP11B2 (5'-TTGCACCAGGTGGAGAGTATG-3' and 5'-GTCGGTTGAGACGCCATTCT- ${ }^{\prime}$ ), and $18 \mathrm{~S}$ rRNA (5'-CGGCTACCACATCCAAGGAA- $3^{\prime}$ and 5'-GCTGGAATTACCGCGGCT-3') for normalization. For renin 2, TaqMan primer sets were used (Applied Biosystems). Changes in the relative gene expression normalized to levels of 18S rRNA were determined using the relative cycle threshold method.

Renin genotyping. Genomic DNA isolated from ear tissue of $\mathrm{sGC}_{1}{ }^{-/-\mathrm{F} 2}$ mice was amplified using primers yielding a 543-bp fragment specific for renin $1 \mathrm{c}$ and renin $1 \mathrm{~d}$ (5'-CGACCCGCAGCATTATCAA- $3^{\prime}$ and 5'-ACTACCGCACAGCCTTCTTCACAT-3'); primers amplifying a 1,100-bp fragment specific for renin 2 (5'-GCCAAGGAGAAGAGACTACAT- $3^{\prime}$ and 5'-CGGGCCAAGGCGAATCCA-3'); and primers amplifying a 695-bp fragment of intergenic DNA in the renin 1c locus but not in the renin $1 \mathrm{~d}-$-renin 2 locus (5'-CAATACGTGTGGTGTAGTCT-3' and 5'-AGGTACTGTGTTAAGGTGGAG-3'). Combination of these 3 PCR reactions allows identification of mice homozygous for renin $1 \mathrm{c}$, homozygous for renin $1 \mathrm{~d}$ and renin 2 , or heterozygous (renin 1c/renin $1 \mathrm{~d}$ and renin 2).

Measurements of plasma aldosterone, plasma Ang II, and blood $\mathrm{Na}^{+}, \mathrm{K}^{+}$, and $B U N$. After anesthetizing male WT and $\mathrm{sGC}_{1}{ }^{-1-}$ mice with $2 \%$ isoflurane, blood was collected, between 8 and 9 a.m., via closed chest cardiac puncture in tubes containing EDTA and immediately placed on ice. After centrifugation at $4,000 \mathrm{~g}$ for 10 minutes at $4^{\circ} \mathrm{C}$, the plasma was isolated and stored at $-80^{\circ} \mathrm{C}$ until analysis. Plasma aldosterone and Ang II levels were measured using an aldosterone EIA kit (Enzo Life Sciences) and an Ang II ELISA kit (Pheonix Pharmaceuticals), respectively, according to the instructions provided by the manufacturer and as described previously $(77,78)$. BUN, $\mathrm{Na}^{+}$, and $\mathrm{K}^{+}$were measured in serum using an Heska Spotchem chemistry analyzer at the Center for Comparative Medicine at Massachusetts General Hospital, Boston.

Treatment with spironolactone, aliskiren, losartan, or enalapril. The renin inhibitor aliskiren $(79,80)$ was administered at a dose of $200 \mathrm{mg} / \mathrm{kg} / \mathrm{d}$ by gavage once daily for 10 days. For treatment with an aldosterone antagonist, mice were implanted with subcutaneous time-release, matrixdriven delivery pellets (Innovative Research of America) releasing 0.24 $\mathrm{mg} / \mathrm{d}$ spironolactone for 7 days (81). Control mice were implanted with placebo pellets. Losartan $(0.1 \mathrm{mg} / \mathrm{kg})$ was administered intravenously. The ACE inhibitor enalapril (82), was added to the drinking water (10 $\mathrm{mg} / 500 \mathrm{ml}$ ) for 3 weeks.

Renal clearance experiments. GFR was measured by inulin clearance as previously described (83). Briefly, male $\mathrm{WT}^{\mathrm{S} 6}$ and $\mathrm{sGC}_{1}{ }^{-/ \mathrm{S} 6}$ mice were anesthetized by i.p. injection of thiobutabarbital sodium (Inactin, SigmaAldrich, $100-120 \mathrm{mg} / \mathrm{kg}$ body weight), and the right jugular vein was catheterized for fluid infusion. The left carotid artery was cannulated for continuous measurement of MAP and blood sampling, and the bladder was cannulated for urine collection. Tritiated inulin $(10 \mu \mathrm{Ci} / \mathrm{ml}$; NEN) in Ringer solution (in mmol/l: $111 \mathrm{NaCl}, 30 \mathrm{NaHCO}_{3}$, and $4.7 \mathrm{KCl}$ ) was intravenously infused at $3 \mu \mathrm{l} / \mathrm{min}$ for assessment of GFR. After surgery and a 60-minute equilibration period, two 30-minute urine samples were collected. Blood samples $(30 \mu \mathrm{l})$ were taken after each clearance period. Plasma and urinary ${ }^{3} \mathrm{H}$-inulin concentration was measured for calculation of GFR. Urine $\mathrm{Na}^{+}$and $\mathrm{K}^{+}$concentrations were measured by flame photometry (type 480 Flame Photometer, Corning Medical and Scientific). Blood pressure, urine volume, $\mathrm{GFR}, \mathrm{E}_{\mathrm{Na}}, \mathrm{E}_{\mathrm{K}}, \mathrm{FE}_{\mathrm{Na}}$, and $\mathrm{FE}_{\mathrm{K}}$ were calculated by standard methods.

Measurement of vascular reactivity in isolated aortic and mesenteric rings. Male WT and $\mathrm{sGC}_{1}{ }^{-/-}$mice were euthanized with pentobarbital $(200 \mathrm{mg} / \mathrm{kg}$, i.p.). Krebs-Henseleit physiological salt solution was prepared as previously described (84). Two milliliters of ice-cold Krebs solution were injected retrograde into the left ventricle, and the thoracic aorta or a mesenteric artery was dissected free of connective and adipose tissue and placed in ice-cold Krebs-Henseleit physiological salt solution pre-equilibrated with $95 \% \mathrm{O}_{2} / 5 \% \mathrm{CO}_{2}$ for 15 minutes. Four rings $2-4 \mathrm{~mm}$ in length per mouse were taken from the aorta or mesenteric artery. Aortic rings were mounted between two tungsten wire hooks and suspended vertically in $10-\mathrm{ml}$ organ baths of the myograph (TSE Systems) containing physiological salt solution and maintained at $37^{\circ} \mathrm{C}, \mathrm{pH} 7.4$, in a mixture of $95 \% \mathrm{O}_{2} / 5 \%$ $\mathrm{CO}_{2}$. The rings were equilibrated for 90 minutes at a resting force of $1.0 \mathrm{~g}$, with replacement of the bathing solution at 15 minute intervals. Mesenteric arteries were mounted onto glass cannulas in a pressure myograph (DMT), maintained at $85 \mathrm{mmHg}$, and perfused as described previously (85). The viability of the vessel was confirmed by measurement of stable and reproducible responses to the addition of phenylephrine $\left(10^{-6} \mathrm{~mol} / \mathrm{l}\right)$. Cumulative concentration-tension response curves to sequential addition of acetylcholine $\left(10^{-9}\right.$ to $\left.10^{-5} \mathrm{~mol} / \mathrm{l}\right)$ were obtained. The integrity of the endothelium was confirmed by a reproducible and stable relaxation of phenylephrine-precontracted rings by acetylcholine. The results of the 4 rings studied per mouse were averaged to yield an $n=1$ per mouse.

Statistics. All continuous measurements are expressed as mean \pm SEM. Statistical comparisons of MAP between multiple strains of mice ( $\mathrm{sGCa}_{1}{ }^{-/-\mathrm{S} 6}$, $\mathrm{sGC} \alpha_{1}^{-/-\mathrm{B} 6}, \mathrm{sGC}_{1}^{-/-\mathrm{F} 2}$ mice or mice with different renin allele combinations, including mice homozygous for the $\mathrm{B} 6$ renin locus or the $\mathrm{S} 6$ renin locus, or mice heterozygous for the renin locus) were performed by 1-way ANOVA with Bonferroni post-hoc testing. A 2-way ANOVA with Bonferroni post-hoc testing was used when comparing gene expression, plasma Ang II levels, plasma aldosterone levels, and MAP in multiple groups (WT ${ }^{\mathrm{S} 6}$, $\mathrm{WT}^{\mathrm{B} 6}, \mathrm{sGC}_{1}{ }^{-/-\mathrm{S} 6}$, and $\mathrm{sGC}_{1}{ }^{-/-\mathrm{B} 6}$ mice, as well as WT and $\mathrm{sGC}_{1^{-/-}}$mice treated with vehicle or a RAAS inhibitor). When comparing two groups (renal clearance studies, MAP), the independent Student's $t$ test was used. The vascular reactivity in aortic rings and mesenteric arteries and the acute effect of losartan on MAP were analyzed by repeated-measures ANOVA. In all cases, a $P$ value less than 0.05 was considered statistically significant.

Study approval. Housing and procedures involving experimental animals (mice) were approved by the Subcommittee on Research Animal Care of Massachusetts General Hospital, the Institutional Animal Care and Use Committee, Yale University, and the Animal Ethical Committee of Ghent University.

\section{Acknowledgments}

This work was supported by Scientist Development Grant 10SDG2610313 from the American Heart Association (to E.S. Buys), an Eleanor and Miles Shore 50th Anniversary Fellowship program for Scholars in Medicine from Harvard Medical School (to E.S. Buys), the Resuscitation Fellowship Award from the American Heart Association and Philips (to P.Y. Sips), a postdoctoral fellowship from CAPES/National Institute of Science and Tech- 
nology in Nanobiopharmaceutics-UFMG (to M.D.G. RodriguesMachado), Fellow-to-Faculty Transition Award 11FTF7290032 from the American Heart Association (to R. Malhotra), the George M. O’Brien Kidney Center at Yale, Core B (to T. Wang), grants from the FWO-Vlaanderen and the UGent-GOA programs (to K. Decaluwé, J. Van de Voorde, and P. Brouckaert), and NHLBI grant R01 HL74352 (to K.D. Bloch) and a grant from the Fondation Leducq (to K.D. Bloch).

1. Fields LE, Burt VL, Cutler JA, Hughes J, Roccella EJ, Sorlie P. The burden of adult hypertension in the United States 1999 to 2000: a rising tide. Hyperten sion. 2004;44(4):398-404.

2. Kung H-C, Hoyert DL, Xu J, Murphy SL. Deaths: final data for 2005. Natl Vital Stat Rep. 2008;56(10):1-120.

3. Newton-Cheh C, et al. Genome-wide association study identifies eight loci associated with blood pressure. Nat Genet. 2009;41(6):666-676.

4. Newton-Cheh $\mathrm{C}$, et al. Association of common variants in NPPA and NPPB with circulating natriuretic peptides and blood pressure. Nat Genet. 2009; 41(3):348-353.

5. Conen D, Cheng S, Steiner LL, Buring JE, Ridker PM, Zee RY. Association of 77 polymorphisms in 52 candidate genes with blood pressure progression and incident hypertension: the Women's Genome Health Study. J Hypertens. 2009;27(3):476-483.

6. Kato N, et al. Meta-analysis of genome-wide association studies identifies common variants associated with blood pressure variation in east Asians. Nat Genet. 2011;43(6):531-538.

7. Ehret GB, et al. Genetic variants in novel pathways influence blood pressure and cardiovascular disease risk. Nature. 2011;478(7367):103-109.

8. Johnson AD, et al. Association of hypertension drug target genes with blood pressure and hypertension in 86,588 individuals. Hypertension. 2011;57(5):903-910.

9. Ruilope LM. Hypertension in 2010: blood pressure and the kidney. Nat Rev Nephrol. 2011;7(2):73-74.

10. Mendelsohn ME. In hypertension, the kidney is not always the heart of the matter. J Clin Invest. 2005;115(4):840-844.

11. Michael SK, et al. High blood pressure arising from a defect in vascular function. Proc Natl Acad SciUS A. 2008;105(18):6702-6707.

12. Rees DD, Palmer RM, Moncada S. Role of endothelium-derived nitric oxide in the regulation of blood pressure. Proc Natl Acad Sci U S A. 1989; 86(9):3375-3378

13. Huang PL, et al. Hypertension in mice lacking the gene for endothelial nitric oxide synthase. Nature. 1995;377(6546):239-242.

14. Panza JA, Quyyumi AA, Brush JE Jr, Epstein SE. Abnormal endothelium-dependent vascular relaxation in patients with essential hypertension. NEngl J Med. 1990;323(1):22-27.

15. Friebe A, Mergia E, Dangel O, Lange A, Koesling D. Fatal gastrointestinal obstruction and hypertension in mice lacking nitric oxide-sensitive guanylyl cyclase. Proc Natl Acad Sci U S A. 2007;104(18):7699-7704

16. Russwurm M, Behrends S, Harteneck C, Koesling D. Functional properties of a naturally occurring isoform of soluble guanylyl cyclase. Biochem J. 1998; 335(pt 1):125-130.

17. Mergia E, Russwurm M, Zoidl G, Koesling D. Major occurrence of the new alpha(2)beta(1) isoform of NO-sensitive guanylyl cyclase in brain. Cell Signal. 2003;15(2):189-195.

18. Buys ES, et al. Gender-specific hypertension and responsiveness to nitric oxide in sGC $\{$ alpha 1 knockout mice. Cardiovasc Res. 2008;79(1):179-186.

19. Nimmegeers S, Sips P, Buys E, Brouckaert P, Van de Voorde J. Functional role of the soluble guanylyl cyclase alpha(1) subunit in vascular smooth muscle relaxation. Cardiovasc Res. 2007;76(1):149-159.

20. Sips PY, Brouckaert P, Ichinose F. The alpha1 iso- form of soluble guanylate cyclase regulates cardiac contractility but is not required for ischemic preconditioning. Basic Res Cardiol. 2011;106(4):635-643.

21. Buys ES, et al. sGC(alpha)1(beta) 1 attenuates cardiac dysfunction and mortality in murine inflammatory shock models. Am J Physiol Heart Circ Physiol. 2009;297(2):H654-H663.

22. Rapp JP, Wang SM, Dene H. A genetic polymorphism in the renin gene of Dahl rats cosegregates with blood pressure. Science. 1989;243(4890):542-544.

23. Piccini N, Knopf JL, Gross KW. A DNA polymorphism, consistent with gene duplication, correlates with high renin levels in the mouse submaxillary gland. Cell. 1982;30(1):205-213.

24. Dickinson DP, Gross KW, Piccini N, Wilson CM Evolution and variation of renin genes in mice. Genetics. 1984;108(3):651-667.

25. Field LJ, Gross KW. Ren-1 and Ren-2 loci are expressed in mouse kidney. Proc Natl Acad Sci U S A. 1985; 82(18):6196-6200.

26. Vanneste G, Dhaese I, Sips P, Buys E, Brouckaert P, Lefebvre RA. Gastric motility in soluble guanylate cyclase alpha 1 knock-out mice. J Physiol. 2007; 584(pt 3):907-920.

27. Atochin DN, et al. Soluble guanylate cyclase alpha1 beta 1 limits stroke size and attenuates neurological injury. Stroke. 2010;41(8):1815-1819.

28. Levy D, et al. Genome-wide association study of blood pressure and hypertension. Nat Genet. 2009; 41(6):677-687.

29. Azam M, Gupta G, Chen W, Wellington S, Warburton D, Danziger RS. Genetic mapping of soluble guanylyl cyclase genes: implications for linkage to blood pressure in the Dahl rat. Hypertension. 1998; 32(1):149-154.

30. Hilbert P, et al. Chromosomal mapping of two genetic loci associated with blood-pressure regulation in hereditary hypertensive rats. Nature. 1991; 353(6344):521-529.

31. Jacob HJ, et al. Genetic mapping of a gene causing hypertension in the stroke-prone spontaneously hypertensive rat. Cell. 1991;67(1):213-224.

32. Deng Y, Rapp JP. Cosegregation of blood pressure with angiotensin converting enzyme and atrial natriuretic peptide receptor genes using Dahl saltsensitive rats. Nat Genet. 1992;1(4):267-272.

33. Wade CM, Daly MJ. Genetic variation in laboratory mice. Nat Genet. 2005;37(11):1175-1180.

34 . Hoit BD, et al. Naturally occurring variation in cardiovascular traits among inbred mouse strains. Genomics. 2002;79(5):679-685.

35. Gurley SB, et al. Altered blood pressure responses and normal cardiac phenotype in ACE2-null mice. J Clin Invest. 2006;116(8):2218-2225.

36. Lum C, Shesely EG, Potter DL, Beierwaltes WH. Cardiovascular and renal phenotype in mice with one or two renin genes. Hypertension. 2004;43(1):79-86.

37. Salzler HR, et al. Hypertension and albuminuria in chronic kidney disease mapped to a mouse chromosome 11 locus. Kidney Int. 2007;72(10):1226-1232.

38. Deng AY, Dene H, Rapp JP. Mapping of a quantitative trait locus for blood pressure on rat chromosome 2. J Clin Invest. 1994;94(1):431-436.

39. Pravenec $M$, et al. Mapping of quantitative trait loci for blood pressure and cardiac mass in the rat by genome scanning of recombinant inbred strains. J Clin Invest. 1995;96(4):1973-1978.
40. Wright FA, et al. Genome scan for blood pressure loci in mice. Hypertension. 1999;34(4 pt 1):625-630.

41. Rapp JP. Genetic analysis of inherited hypertension in the rat. Physiol Rev. 2000;80(1):135-172.

42. Stoll M, et al. New target regions for human hypertension via comparative genomics. Genome Res. 2000; 10(4):473-482.

43. Moore N, et al. Renin gene polymorphisms and haplotypes, blood pressure, and responses to reninangiotensin system inhibition. Hypertension. 2007; 50(2):340-347.

44. Ehret GB, O'Connor AA, Weder A, Cooper RS, Chakravarti A. Follow-up of a major linkage peak on chromosome 1 reveals suggestive QTLs associated with essential hypertension: GenNet study. Eur J Hum Genet. 2009;17(12):1650-1657.

45. Kobori H, Nangaku M, Navar LG, Nishiyama A. The intrarenal renin-angiotensin system: from physiology to the pathobiology of hypertension and kidney disease. Pharmacol Rev. 2007;59(3):251-287.

46. Peters J, Munter K, Bader M, Hackenthal E, Mullins $\mathrm{JJ}$, Ganten D. Increased adrenal renin in transgenic hypertensive rats, TGR(mREN2)27, and its regulation by cAMP, angiotensin II, and calcium. J Clin Invest. 1993;91(3):742-747.

47. Jacke K, Witte K, Lemmer B. Mechanisms involved in the blunted nitric oxide-cGMP pathway in hypertensive TGR(mREN2)27 rats. Eur J Pharmacol. 2001;415(1):27-30.

48. Campbell DJ, Valentijn AJ, Condron R. Purification and amino-terminal sequence of rat kidney renin: evidence for a two-chain structure. J Hypertens. 1991; 9(1):29-33.

49. Inagami T. Structure and function of renin. J Hypertens Suppl. 1989;7(2):S3-S8.

50. Brunner $\mathrm{H}$, et al. Endothelial function and dysfunction. Part II: association with cardiovascular risk factors and diseases. A statement by the Working Group on Endothelins and Endothelial Factors of the European Society of Hypertension. J Hypertens. 2005;23(2):233-246.

51. Stasch JP, Pacher P, Evgenov OV. Soluble guanylate cyclase as an emerging therapeutic target in cardiopulmonary disease. Circulation. 2011; 123(20):2263-2273

52. Wagner C, Kurtz A. Regulation of renal renin release. Curr Opin Nephrol Hypertens. 1998;7(4):437-441.

53. Lu M, Wang X, Wang W. Nitric oxide increases the activity of the apical $70-\mathrm{pS} \mathrm{K}+$ channel in TAL of rat kidney. Am J Physiol. 1998; 274(5 pt 2):F946-F950.

54. Wang WH. The cGMP-dependent protein kinase stimulates the basolateral 18-pS K channel of the rat CCD. Am J Physiol Cell Physiol. 2000; 278(6):C1212-C1217.

55. Maron BA, et al. Aldosterone increases oxidant stress to impair guanylyl cyclase activity by cysteinyl thiol oxidation in vascular smooth muscle cells. J Biol Chem. 2009;284(12):7665-7672.

56. Crowley SD, et al. Distinct roles for the kidney and systemic tissues in blood pressure regulation by the renin-angiotensin system. J Clin Invest. 2005; 115(4):1092-1099.

57. Pentz ES, Lopez ML, Kim HS, Carretero O, Smithies O, Gomez RA. Ren1d and Ren2 cooperate to preserve homeostasis: evidence from mice expressing GFP in place of Ren1d. Physiol Genomics. 2001;6(1):45-55. 
58. Hatakeyama H, Miyamori I, Fujita T, Takeda Y, Takeda R, Yamamoto H. Vascular aldosterone. Biosynthesis and a link to angiotensin II-induced hypertrophy of vascular smooth muscle cells. J Biol Chem. 1994;269(39):24316-24320.

59. Jaffe IZ, et al. Placental growth factor mediates aldosterone-dependent vascular injury in mice. J Clin Invest. 2010;120(11):3891-3900.

60. Cat AN, Touyz RM. A new look at the renin-angiotensin system - focusing on the vascular system. Peptides. 2011;32(10):2141-2150.

61. Romagni P, Rossi F, Guerrini L, Quirini C, Santiemma $\mathrm{V}$. Aldosterone induces contraction of the resistance arteries in man. Atherosclerosis. 2003;166(2):345-349.

62. Schmidt BM, et al. Rapid nongenomic effects of aldosterone on human forearm vasculature. Hypertension. 2003;42(2):156-160

63. Meurer S, et al. Nitric oxide-independent vasodilator rescues heme-oxidized soluble guanylate cyclase from proteasomal degradation. Circ Res. 2009; 105(1):33-41.

64. Stasch JP, et al. Targeting the heme-oxidized nitric oxide receptor for selective vasodilatation of diseased blood vessels. J Clin Invest. 2006;116(9):2552-2561.

65. Reckelhoff JF. Sex steroids, cardiovascular disease, and hypertension: unanswered questions and some speculations. Hypertension. 2005;45(2):170-174.

66. Ingelfinger JR, Pratt RE, Roth TP, Dzau VJ. Processing of one-chain to two-chain renin in the mouse submandibular gland is influenced by androgen. Pediatr Res. 1989;25(4):332-335.

67. Tronik D, Rougeon F. Thyroxine and testosterone transcriptionally regulate renin gene expression in the submaxillary gland of normal and transgenic mice carrying extra copies of the Ren 2 gene. FEBS Lett. 1988;234(2):336-340.

68. Baltatu O, Cayla C, Iliescu R, Andreev D, Jordan C, Bader M. Abolition of hypertension-induced endorgan damage by androgen receptor blockade in transgenic rats harboring the mouse ren- 2 gene. J Am Soc Nephrol. 2002;13(11):2681-2687.

69. Krege JH, et al. Male-female differences in fertility and blood pressure in ACE-deficient mice. Nature. 1995;375(6527):146-148.

70. O'Donnell CJ, et al. Evidence for association and genetic linkage of the angiotensin-converting enzyme locus with hypertension and blood pressure in men but not women in the Framingham Heart Study. Circulation. 1998;97(18):1766-1772.

71. Evgenov OV, Pacher P, Schmidt PM, Hasko G, Schmidt HH, Stasch JP. NO-independent stimulators and activators of soluble guanylate cyclase: discovery and therapeutic potential. Nat Rev Drug Discov. 2006;5(9):755-768.

72. Stasch JP, Dembowsky K, Perzborn E, Stahl E, Schramm M. Cardiovascular actions of a novel NOindependent guanylyl cyclase stimulator, BAY 41-8543: in vivo studies. BrJ Pharmacol. 2002;135(2):344-355.

73. Brandes RP, et al. Increased nitrovasodilator sensitivity in endothelial nitric oxide synthase knockout mice: role of soluble guanylyl cyclase. Hypertension. 2000;35(1 pt 2):231-236.

74. Kruglyak L, Lander ES. A nonparametric approach for mapping quantitative trait loci. Genetics. 1995; 139(3):1421-1428.

75. Lander E, Kruglyak L. Genetic dissection of complex traits: guidelines for interpreting and reporting linkage results. Nat Genet. 1995;11(3):241-247.
76. Lander ES, Botstein D. Mapping mendelian factors underlying quantitative traits using RFLP linkage maps. Genetics. 1989;121(1):185-199.

77. Aoyagi T, et al. Vasopressin regulates the reninangiotensin-aldosterone system via $V 1$ a receptors in macula densa cells. Am J Physiol Renal Physiol. 2008;295(1):F100-F107.

78. Kapur NK, et al. Hemodynamic modulation of endocardial thromboresistance. Circulation. 2007; 115(1):67-75.

79. Brown MJ. Aliskiren. Circulation. 2008; 118(7):773-784.

80. Jensen C, Herold P, Brunner HR. Aliskiren: the first renin inhibitor for clinical treatment. Nat Rev Drug Discov. 2008;7(5):399-410.

81. Williams JS. Hypertension: spironolactone and resistant hypertension. Nat Rev Endocrinol. 2010;6(5):248-250.

82. Jacke K, Witte K, Huser L, Behrends S, Lemmer B. Contribution of the renin-angiotensin system to subsensitivity of soluble guanylyl cyclase in TGR(mREN2)27 rats. Eur J Pharmacol. 2000;403(1-2):27-35

83. Wang T, Inglis FM, Kalb RG. Defective fluid and $\mathrm{HCO}(3)(-)$ absorption in proximal tubule of neuronal nitric oxide synthase-knockout mice. Am J Physiol Renal Pbysiol. 2000;279(3):F518-F524.

84. Yu B, et al. Endothelial dysfunction enhances vasoconstriction due to scavenging of nitric oxide by a hemoglobin-based oxygen carrier. Anesthesiology. 2010;112(3):586-594.

85. Atochin DN, et al. The phosphorylation state of eNOS modulates vascular reactivity and outcome of cerebral ischemia in vivo. J Clin Invest. 2007; 117(7):1961-1967. 